\title{
MOLECULAR AND SOLID STATE STRUCTURE OF THE DOUBLY-SUBSTITUTED B-DIKETONE 3,3'-BIS(FERROCENYLMETHYL)PENTANE-2,4-DIONE ${ }^{\#}$
}

\author{
GUILLERMO AHUMADA ${ }^{a}$, THIERRY ROISNEL ${ }^{b}, J E A N-R E N E ́$ HAMON ${ }^{b *}$ \\ DAVID CARRILLO ${ }^{a}$, CAROLINA MANZUR ${ }^{*}$ \\ ${ }^{a}$ Laboratorio de Química Inorgánica, Instituto de Química, Pontificia Universidad Católica de Valparaíso, \\ Campus Curauma, Avenida Universidad 330, Valparaiso, Chile \\ ${ }^{b} U M R 6226$ «Institut des Sciences Chimiques de Rennes», CNRS-Université de Rennes 1, Campus de Beaulieu, 35042 Rennes Cedex, France
}

(Received: May 27, 2013 - Accepted: October 9, 2013)

\begin{abstract}
The ferrocene-containing $\beta$-diketone, 3-ferrocenylmethyl-pentane-2,4-dione 1, has been synthesized by reacting ferrocenyl methanol with acetylacetone in the presence of cerium(IV) ammonium nitrate as catalyst in C-C bond formation, and isolated as an orange oily product in $90 \%$ yield. The doubly-substituted 1,3-diketone, 3,3'-bis(ferrocenylmethyl)pentane-2,4-dione $\mathbf{2}$ was isolated as orange crystals in $79 \%$ yield, upon standing a dichloromethane solution of $\mathbf{1}$ at -30 ${ }^{\circ} \mathrm{C}$ for two weeks. Both complexes have been authenticated by spectroscopic methods, mass spectrometry, and cyclic voltammetry. In addition, the molecular identity and geometry of $\mathbf{2}$ has been confirmed by single-crystal X-ray diffraction analysis. In the crystal lattice, the molecules pack as dimers through $\mathrm{C}$ - $\mathrm{H} \cdots \mathrm{O}$ hydrogen bondings, where weaker $\mathrm{C}-\mathrm{H} \cdots \mathrm{p}$ interactions link the dimeric units to form a chain structure.
\end{abstract}

Keywords: Ferrocene; 1,3-dione; catalyzed C-C coupling; bimetallic complex; X-ray structure

\section{INTRODUCTION}

$\beta$-Diketones are an important class of organic compounds frequently encountered in synthetic chemistry, ${ }^{1,2}$ where in addition to their established role in the synthesis of various heterocyclic derivatives which have been widely studied and reviewed, ${ }^{3-6}$ they have been used as ligands for the coordination of transition metals. ${ }^{7,8}$ On the other hand, $\beta$-diketones are attractive building blocks for the construction of polydentate Schiff bases, and both the parent derivative 2,4-pentanedione $\left(\mathrm{CH}_{3} \mathrm{COCH}_{2} \mathrm{COCH}_{3}\right)^{9}{ }^{9-12}$ and its organometallic counterpart ferrocenoylacetone $\left(\mathrm{FcCOCH}_{2} \mathrm{COCH}_{3},{ }^{13} \mathrm{Fc}=\left(\mathrm{h}^{5}-\mathrm{C}_{5} \mathrm{H}_{5}\right) \mathrm{Fe}\left(\mathrm{h}^{5}-\right.\right.$ $\left.\mathrm{C}_{5} \mathrm{H}_{4}\right)$ ) have been widely employed to prepare tridentate Schiff base complexes, also called half-units, upon mono-condensation with primary diamines. ${ }^{14-22}$ In pursuit of our research work aimed at extending the scope of acyclic Schiff base metalloligands, ${ }^{14-17}$ we decided to synthetize new $\beta$-diketones functionalized at the central carbon of the 1,3-dione system, using cerium(IV) ammonium nitrate (CAN), a versatile reagent in a variety of synthetic transformations through oxidation of organic molecules, ${ }^{23-25}$ as catalyst in the carbon-carbon bond formation between ferrocenyl alcohol substrates and 1,3-diketones. ${ }^{26}$ Accordingly, we were able to isolate and structurally characterize three new chiral ferrocene-containing diketones starting from 1 -ferrocenyl ethanol. ${ }^{27}$ As a model reaction for this previous work, we tested the CAN-mediated C-C coupling reaction between achiral ferrocenyl methanol and acetylacetone. Herein, we wish to report on the outcome of this reaction and on the molecular and crystal structure of the doubly-substituted complex 3,3'-bis(ferrocenylmethyl)pentane-2,4-dione 2 (see Scheme 1 for formula).

\section{EXPERIMENTAL}

\section{General}

Reactions were performed under dry nitrogen atmosphere using standard Schlenk techniques. Solvents were dried and distilled under dinitrogen by standard methods prior to use. All chemicals were purchased from commercial sources and used without further purification. Ferrocenylmethanol was prepared according to the literature method. ${ }^{28}$ FT-IR spectra were recorded on a Perkin Elmer model 1600 FT-IR spectrophotometer, in the range 4000$450 \mathrm{~cm}^{-1}$. ${ }^{1} \mathrm{H}$ NMR spectra were recorded on a $400 \mathrm{MHz}$ Bruker Avance III 400 spectrometer at $298 \mathrm{~K}$. Chemical shifts $(d)$ are reported in parts per million $(\mathrm{ppm})$ and referenced to the residual deuterated solvent peaks $\left(\mathrm{CDCl}_{3}\right.$ : ${ }^{1} \mathrm{H} d=7.26 \mathrm{ppm}$ ). High resolution electrospray mass spectra (HR-ESI-MS) were collected on a Bruker Q-Tof 2 spectrometer at the Centre Régional de Mesures Physiques de l'Ouest (CRMPO, Université de Rennes 1, France). Cyclic voltammetry (CV) measurements were performed using a Radiometer Analytical model PGZ 100 all-in one potentiostat, using a three-electrode CEMM with glassy carbon working, $\mathrm{Ag} / \mathrm{AgCl}$ reference and platinum wire auxiliary electrodes. The ferrocene/ferrocenium $\left(\mathrm{FcH}^{0 /+}\right)$ couple was located at $E_{1 / 2}=0.488 \mathrm{~V}$, where $E_{12}$ was calculated from the average of the oxidation and reduction peak potentials. Melting points were measured in evacuated capillaries on a Kofler Bristoline melting point apparatus and are uncorrected.

Synthesis of 3-ferrocenylmethyl-pentane-2,4-dione (1)

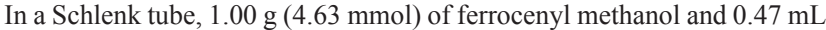
$(4.7 \mathrm{mmol})$ of 2,4 pentanedione were dissolved in $8 \mathrm{~mL}$ of acetonitrile at room temperature (rt). After $5 \mathrm{~min}$ of stirring, $0.125 \mathrm{~g}(0.23 \mathrm{mmol})$ of cerium(IV) ammonium nitrate $(5 \%$ molar) were added. The reaction mixture was stirred for $30 \mathrm{~min}$ at $\mathrm{rt}$ and then evaporated under reduced pressure. The solid residue was mixed with $5 \mathrm{~mL}$ of water and extracted with $10 \mathrm{~mL}$ of dichloromethane. The organic phase was dried over $\mathrm{MgSO}_{4}$, filtered off and evaporated under reduced pressure to afford $1.25 \mathrm{~g}(4.29 \mathrm{mmol}, 90 \%$ yield $)$ of $\mathbf{1}$ as an orange oil. FT-IR ( $\left.\mathrm{KBr}, \mathrm{cm}^{-1}\right): 1726$ (s), 1696 (vs) $n(\mathrm{C}=\mathrm{O}) .{ }^{1} \mathrm{H}$ NMR $\left(400 \mathrm{MHz}, \mathrm{CDCl}_{3}\right)$ : $2.09\left(\mathrm{~s}, 6 \mathrm{H}, \mathrm{CH}_{3}\right), 2.88\left(\mathrm{~s}, 2 \mathrm{H}, \mathrm{CH}_{2}\right), 3.75(\mathrm{~s}, 1 \mathrm{H}, \mathrm{CH}), 3.99$ (br s, $\left.2 \mathrm{H}, \mathrm{C} 5 \mathrm{H} 4\right)$, $4.03\left(\mathrm{br} \mathrm{s}, 2 \mathrm{H}, \mathrm{C}_{5} H_{4}\right), 4.09\left(\mathrm{~s}, 5 \mathrm{H}, \mathrm{C}_{5} \mathrm{H}_{5}\right)$.

Isolation of 3,3'-bis(ferrocenylmethyl)pentane-2,4-dione (2)

The prepared above oily product $1(1.25 \mathrm{~g}, 4.29 \mathrm{mmol})$ was recrystallized from a saturated dichloromethane solution at $-30^{\circ} \mathrm{C}$ for two weeks, depositing orange crystals of 2 . Yield: $0.91 \mathrm{~g}(1.83 \mathrm{mmol}), 79 \%$. Suitable single crystals for the X-ray diffraction studies were selected from this crop. M.p. $172^{\circ} \mathrm{C}$ (lit. 170-172 ${ }^{\circ} \mathrm{C}$ ).$^{29} \mathrm{HRMS}$ positive ESI, [m/z] calcd for $\mathrm{C}_{27} \mathrm{H}_{28} \mathrm{O}_{2}{ }^{56} \mathrm{Fe}_{2}: 496.07826$; found: 496.0780 (relative error: $0 \mathrm{ppm})$ [M].+. FT-IR $\left(\mathrm{KBr}, \mathrm{cm}^{-1}\right): 3115(\mathrm{w})$ $n(\mathrm{C}-\mathrm{H}$ arom); 2956(m), 2938(m), 2923(m), 2854(m) $n(\mathrm{C}-\mathrm{H}$ aliph); 1696(vs) $n(\mathrm{C}=\mathrm{O}) .{ }^{1} \mathrm{H}$ NMR $\left(400 \mathrm{MHz}, \mathrm{CDCl}_{3}\right): 2.10\left(\mathrm{~s}, 6 \mathrm{H}, \mathrm{CH}_{3}\right), 2.79\left(\mathrm{~s}, 4 \mathrm{H}, \mathrm{CH}_{2}\right)$, $4.12\left(\mathrm{br} \mathrm{s}, 18 \mathrm{H}, \mathrm{C}_{5} H_{4}+\mathrm{C}_{5} H_{5}\right)$.

\section{Crystal structure determination}

X-ray data for an orange crystal of $\mathbf{2}$, obtained as described above, were collected at 150(2) $\mathrm{K}$ on a Bruker APEXII AXS diffractometer, equipped with a CCD detector, using Mo-Ka radiation $(1=0.71073 \AA)$. The crystal of approximate dimensions $0.57 \times 0.45 \times 0.19 \mathrm{~mm}$, was coated in Paratone- $\mathrm{N}$ oil and mounted on a Kaptan loop. The loop was transferred to the diffractometer, centered in the beam, and cooled by a nitrogen flow low-temperature apparatus that had been previously calibrated by a thermocouple placed at the same position as the crystal. The structure was solved by direct methods using SIR97 program,$^{30}$ and then refined with full-matrix least-square methods based on $F^{2}$ (SHELXL-97), ${ }^{31}$ with the aid of WINGX program. ${ }^{32}$ All non-hydrogen atoms were refined with anisotropic atomic displacement parameters. Hydrogen atoms were finally included in their calculated positions. A summary of the details about crystal data, collection parameters and refinement are documented in Table 1, and additional crystallographic details are in the CIF file. ORTEP and ball-and-stick views are generated using OLEX2. ${ }^{33}$ 
Table 1. Crystallographic data, details of data collection and structure refinement parameters for compound $\mathbf{2}$

\begin{tabular}{|c|c|}
\hline Empirical Formula & $\mathrm{C}_{27} \mathrm{H}_{28} \mathrm{Fe}_{2} \mathrm{O}_{2}$ \\
\hline Formula mass, $\mathrm{g} \mathrm{mol}^{-1}$ & 496.19 \\
\hline Collection $\mathrm{T}, \mathrm{K}$ & $150(2)$ \\
\hline crystal system & Monoclinic \\
\hline space group & $\mathrm{P} 2{ }_{1} / \mathrm{n}$ \\
\hline$a(\AA)$ & $11.0975(3)$ \\
\hline$b(\AA)$ & $17.7800(4)$ \\
\hline$c(\AA)$ & $12.0807(3)$ \\
\hline$\beta\left(^{\circ}\right)$ & $114.9110(10)$ \\
\hline$V\left(\AA^{3}\right)$ & 2161.91(9) \\
\hline$Z$ & 4 \\
\hline$D_{\text {calcd }}\left(\mathrm{g} \mathrm{cm}^{-3}\right)$ & 1.524 \\
\hline$F(000)$ & 1032 \\
\hline $\operatorname{abs} \operatorname{coeff}\left(\mathrm{mm}^{-1}\right)$ & 1.364 \\
\hline$\theta$ range $\left(^{\circ}\right)$ & 3.47 to 27.48 \\
\hline range $h, k, 1$ & $\begin{array}{l}-12 / 14,-22 / 22,- \\
15 / 15\end{array}$ \\
\hline No. total refl. & 17245 \\
\hline No. unique refl. & 4871 \\
\hline Comp. to $\theta_{\max }(\%)$ & 98.3 \\
\hline $\mathrm{Max} / \mathrm{min}$ transmission & $0.772 / 0.571$ \\
\hline Data/Restraints/Parameters & $4871 / 0 / 282$ \\
\hline $\begin{array}{l}\text { Final R } \\
{[I>2 \sigma(I)]}\end{array}$ & $\begin{array}{l}\mathrm{R}_{1}=0.0314 \\
\mathrm{wR}_{2}=0.0767\end{array}$ \\
\hline $\mathrm{R}$ indices (all data) & $\begin{array}{l}\mathrm{R}_{1}=0.0393 \\
\mathrm{Wr}_{2}=0.0809\end{array}$ \\
\hline $\begin{array}{l}\text { Goodness of fit / } \mathrm{F}^{2} \\
\text { Largest diff. Peak/hole }\left(\mathrm{e}^{-3}\right)\end{array}$ & $\begin{array}{l}1.072 \\
0.620 \text { and }-0.372\end{array}$ \\
\hline
\end{tabular}

\section{RESULTS AND DISCUSSION}

\section{Synthesis and characterization}

Reacting equimolar amounts of ferrocenyl methanol and acetylacetone in the presence of $5 \mathrm{~mol} \% \mathrm{CAN}$ as the catalyst, in acetonitrile for $30 \mathrm{~min}$ at room temperature, ${ }^{12}$ leads to the formation of the symmetrical diketone 3 -ferrocenylmethyl-pentane-2,4-dione (1), that was isolated as an orange oily product in $90 \%$ yield (Scheme 1). Orange crystals of 3,3'-bis-(ferrocenylmethyl) pentane-2,4-dione (2) deposited upon standing a dichloromethane solution of compound $\mathbf{1}$ at $-30{ }^{\circ} \mathrm{C}$ for two weeks. Compound 2, resulting from a double substitution of ferrocenylmethyl units at the activated methylene carbon of the pentane-2,4-dione, was isolated in 79\% yield. Both compounds $\mathbf{1}$ and $\mathbf{2}$, that are air and thermally stable, were previously obtained by Glidewel et al. ${ }^{29} \mathbf{1}$ was isolated in $78 \%$ yield upon refluxing equimolar quantities of ferrocenylmethyl-trimethylammonium iodide and the monosodium salt of the acetylacetone in dry acetonitrile for $15 \mathrm{~h}$, whereas crystals of $\mathbf{2}$ deposited when the oil $\mathbf{1}$ was kept for six months. In addition to the reported analytical and spectroscopic characterization of $\mathbf{2},{ }^{15}$ we provide here the full details of its crystalline structure determination. ${ }^{34}$
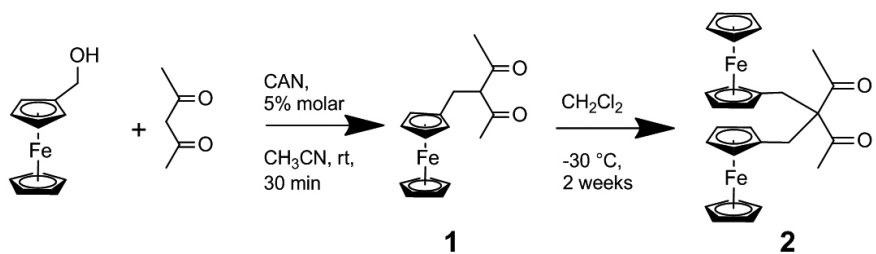

Scheme 1. Synthesis of complexes 1 and 2.
The 3-ferrocenylmethyl-pentane-2,4-dione (1) was characterized in its solid-state FT-IR spectrum by two strong bands at 1726 and $1696 \mathrm{~cm}^{-1}$, while that of 2 presents one intense band at $1696 \mathrm{~cm}^{-1}$ attributed, in both cases, to the $n(\mathrm{C}=\mathrm{O})$ stretching vibrations of the acetyl groups. The ${ }^{1} \mathrm{H}$ NMR spectrum of $\mathbf{1}$ in $\mathrm{CDCl}_{3}$ solution shows only the keto tautomer with a signal integrating for 1 $\mathrm{H}$ at $3.75 \mathrm{ppm}$, assigned to the $\mathrm{C}-\mathrm{H}$ proton, in agreement with our earlier work on 1,3-diketone-containing ethylferrocenes, ${ }^{27}$ but in contrast to the $3: 1$ keto:enol ratio previously reported for $1 .{ }^{29}$ Owing to its high symmetry, the ${ }^{1} \mathrm{H}$ NMR spectrum of $\mathbf{2}$ is remarkably simple and in accordance with the reported one: ${ }^{29}$ it exhibits two sharp singlets at $2.10(6 \mathrm{H})$ and $2.79(4 \mathrm{H}) \mathrm{ppm}$, attributable to the acetyl and methylene protons, respectively, and a broad resonance at 4.12 $\mathrm{ppm}$ assigned to the 18 protons of the two equivalent ferrocenyl moieties.

The mass spectrum of the disubstituted product 2 shows a strong molecular ion peak at $\mathrm{m} / \mathrm{z}=496$ that agrees with the value expected for the radical cation $[\mathrm{M}]^{+}$, as well as a prominent fragment ions at $\mathrm{M} / \mathrm{z}=199$ that is assigned as the cation $\left[\mathrm{FCCH}_{2}\right]^{+}$. This later ion is also observed in the mass spectrum of the doubly-substituted diketone derived from the cyclohexane-1,3-dione. ${ }^{29}$

\section{X-ray diffraction study}

Orange X-ray quality crystals of 3,3'-bis(ferrocenylmethyl)pentane2,4-dione (2) were obtained upon cooling a dichloromethane solution of 1 (see Experimental section). Complex 2 crystallizes in the monoclinic centrosymmetric space group $\mathrm{P} 2 / \mathrm{n}$ with a single molecule in the asymmetric unit. The central $\mathrm{C}(12)$ carbon atom lies on a two-fold rotation axis. The molecular structure of $\mathbf{2}$ with the atom labeling scheme is displayed in Figure 1 with selected bond distances and angles given in Table 2. Complex 2 consists of two ferrocenylmethyl moieties joined to the central carbon of a pentane-2,4-dione backbone. In both ferrocenyl moieties, $\mathrm{Fc} 1$ and $\mathrm{Fc} 2$, the two cyclopentadienyl rings are nearly eclipsed with twist angles of $1.99^{\circ}$ for $\mathrm{Fc} 1$ and $7.24^{\circ}$ for $\mathrm{F} c 2$, and they are slightly bent with dihedral angles of $1.86(14)^{\circ}$ and $2.37(12)^{\circ}$, respectively. The iron atoms are coordinated to their respective free and substituted cyclopentadienyl rings at a ring centroid-iron distances of 1.649/1.647 $\AA$ for Fc1 and 1.650/1.646 $\AA$ for Fc2. Those metrical parameters feature linear sandwich structures with typical $\left[\mathrm{h}^{5}-\mathrm{Fe}(\mathrm{II})-\mathrm{h}^{5}\right]$ coordination mode. ${ }^{35}$

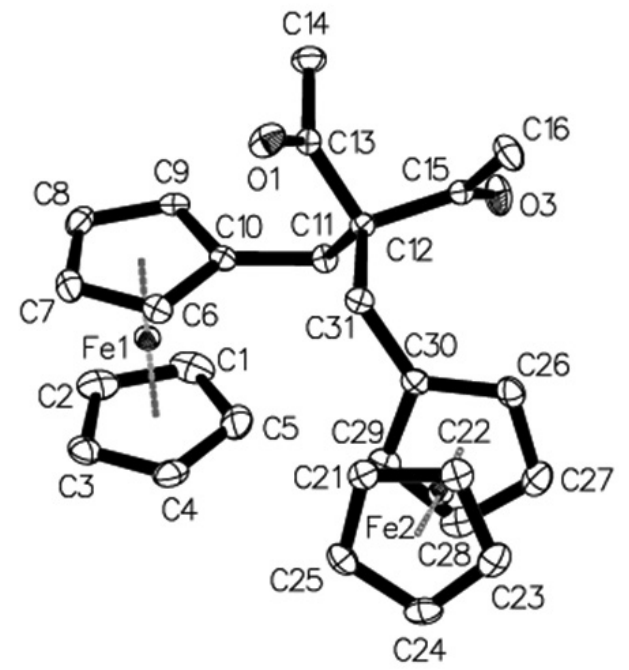

Figure 1. Molecular structure of $\mathbf{2}$ with the atom numbering scheme. The thermal ellipsoids are drawn at the $40 \%$ probability level and the hydrogen atoms are omitted for clarity.

The two identical $\mathrm{C}(13)-\mathrm{O}(1)$ and $\mathrm{C}(15)-\mathrm{O}(3)$ bond distances (1.204(2) $\AA$ ) are close to the typical $\mathrm{C}=\mathrm{O}$ double bond length $(1.21 \AA),{ }^{36}$ as found for other structurally characterized non-enolized 1,3 -diketones. ${ }^{27,37}$ The lengths of the $\mathrm{C}-\mathrm{C}$ in the connecting tetrahedral core, and of the $\mathrm{C}-\mathrm{C}$ and $\mathrm{C}-\mathrm{Fe}$ bonds in the ferrocene sandwiches (see Table 2) fall all within the range of standard values. $^{36,38}$ The bond angles at the central carbon $C(12)$ averaging $107.77(15)^{\circ}$, is an idealized value for $\mathrm{sp}^{3}$-hybridized atom, whereas the acetyl $\mathrm{O}(1)$ $\mathrm{C}(13)-\mathrm{C}(14)$ and $\mathrm{O}(3)-\mathrm{C}(15)-\mathrm{C}(16)$ angles of $121.17(18)^{\circ}$ and $120.51(18)^{\circ}$, respectively, are those expected for $\mathrm{sp}^{2}$-hybridized acetyl carbonyl carbons and similar to values, ranging from $119.35(16)^{\circ}$ to $124.0(8)^{\circ}$, we measured earlier for such bond angles. ${ }^{27,39}$ 
Table 2. Selected bond distances $(\AA)$ and angles $\left(^{\circ}\right)$ for compound 2.

\begin{tabular}{|c|c|c|c|}
\hline \multicolumn{5}{|c|}{ Bond distances } \\
\hline $\mathrm{C}(10)-\mathrm{C}(11)$ & $1.504(3)$ & $\mathrm{C}(30)-\mathrm{C}(31)$ & $1.505(3)$ \\
\hline $\mathrm{C}(11)-\mathrm{C}(12)$ & $1.549(3)$ & $\mathrm{C}(12)-\mathrm{C}(31)$ & $1.553(3)$ \\
\hline $\mathrm{C}(12)-\mathrm{C}(13)$ & $1.549(3)$ & $\mathrm{C}(12)-\mathrm{C}(15)$ & $1.545(3)$ \\
\hline $\mathrm{C}(13)-\mathrm{O}(1)$ & $1.204(2)$ & $\mathrm{C}(15)-\mathrm{O}(3)$ & $1.204(2)$ \\
\hline $\mathrm{Fe}(1)-\mathrm{C}_{\mathrm{Cp}}$ avg & 2.043 & $\mathrm{Fe}(2)-\mathrm{C}_{\mathrm{Cp}}$ avg & 2.047 \\
\hline $\mathrm{Fe}(1)-\mathrm{C}_{\mathrm{Cp}}, \mathrm{avg}$ & 2.045 & $\mathrm{Fe}(2)-\mathrm{C}_{\mathrm{Cp}}$, avg & 2.045 \\
\hline \multicolumn{4}{|c|}{ Angles } \\
\hline $\mathrm{C}(11)-\mathrm{C}(12)-\mathrm{C}(31)$ & $111.57(15)$ & $\mathrm{C}(13)-\mathrm{C}(12)-\mathrm{C}(15)$ & $105.92(15)$ \\
\hline $\mathrm{C}(12)-\mathrm{C}(13)-\mathrm{O}(1)$ & $121.90(17)$ & $\mathrm{C}(12)-\mathrm{C}(15)-\mathrm{O}(3)$ & $121.53(18)$ \\
\hline $\mathrm{C}(12)-\mathrm{C}(13)-\mathrm{C}(14)$ & $116.93(16)$ & $\mathrm{C}(12)-\mathrm{C}(15)-\mathrm{C}(16)$ & $117.93(16)$ \\
\hline $\mathrm{C}(12)-\mathrm{C}(11)-\mathrm{C}(10)$ & $115.36(15)$ & $\mathrm{C}(12)-\mathrm{C}(31)-\mathrm{C}(30)$ & $112.95(15)$ \\
\hline
\end{tabular}

Abbreviations: $\mathrm{Cp}=\mathrm{C}_{5} \mathrm{H}_{5}, \mathrm{Cp}^{\prime}=\mathrm{C}_{5} \mathrm{H}_{4}$.

Within the crystal structure of $\mathbf{2}$ there are several short intermolecular contacts. ${ }^{40}$ Two intermolecular C-H $\cdots$ O hydrogen bond interactions (Table 3) are observed in the molecule forming a dimeric unit (Figure 2). Moreover, the packing is effected by an intermolecular cyclopentadienyl- $\mathrm{H} \cdots \mathrm{p}$ interaction $\mathrm{C}(21)-\mathrm{H}(21) \cdots \mathrm{Cg}_{2}\left(\mathrm{C}(21)-\mathrm{H}(21)=0.95 \AA, \mathrm{H}(21) \cdots \mathrm{Cg}_{2}=2.79 \AA, \mathrm{C}(21) \cdots \mathrm{Cg}_{2}\right.$ $=3.601(2) \AA, C(21)-\mathrm{H}(21) \cdots \mathrm{Cg}_{2}=143^{\circ}$; symmetry code: $\left.1-\mathrm{x},-\mathrm{y}, 1-\mathrm{z}\right)$. It is weaker than the hydrogen bonding interactions, but plays a key role in the packing pattern in creating a chain structure of dimers (Figure 2).

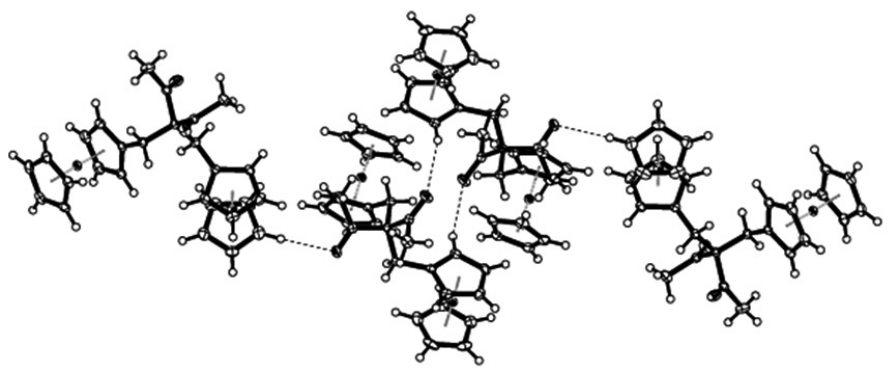

Figure 2. Intermolecular hydrogen bond interactions forming a chain structure of dimers of 2 .

Table 3. Hydrogen bonding interaction parameters for $\mathbf{2}$

\begin{tabular}{|c|c|c|c|c|}
\hline D-H $\cdots \mathrm{A}$ & $\mathrm{D}-\mathrm{H}(\AA)$ & $\mathrm{H} \cdots \mathrm{A}(\AA)$ & $\mathrm{D} \cdots \mathrm{A}(\AA)$ & $\begin{array}{c}\mathrm{D}-\mathrm{H} \cdots \mathrm{A} \\
\left({ }^{\circ}\right)\end{array}$ \\
\hline $\mathrm{C}(2)-\mathrm{H}(2) \cdots \mathrm{O}(3)^{\mathrm{i}}$ & 0.95 & 2.41 & $3.363(3)$ & 177 \\
\hline $\mathrm{C}(6)-\mathrm{H}(6) \cdots \mathrm{O}(1)^{\mathrm{ii}}$ & 0.95 & 2.49 & $3.347(3)$ & 150 \\
\hline
\end{tabular}

Symmetry Codes: (i)-1/2+x,1/2-y,1/2+z; (ii) $1-x,-y, 1-z$

\section{Cyclic voltammetry}

The electrochemical features of compounds $\mathbf{1}$ and $\mathbf{2}$ were investigated by cyclic voltammetry in dichloromethane solution containing $0.1 \mathrm{M}\left[n-\mathrm{Bu}_{4} \mathrm{~N}\right]$ $[\mathrm{PF}]$ as supporting electrolyte. Measurements were carried out in $10^{-3} \mathrm{M}$ solutions at room temperature in the potential range +1.5 to $-1.0 \mathrm{~V}$ with scan rate $10 \mathrm{mV} \mathrm{s}^{-1}$. Cyclic voltammograms of solutions containing $\mathbf{1}$ and $\mathbf{2}$ show in both cases a chemically reversible oxidation process with current ratio $i_{\text {I }}$ $i_{\mathrm{pc}}$ equal to unity, at $E_{1 / 2}$ values of 0.475 and $0.523 \mathrm{~V} / \mathrm{SCE}$, respectively. As expected, the wave intensity of the doubly-substituted derivative $\mathbf{2}$ is two-fold that of its precursor $\mathbf{1}$. In compound $\mathbf{2}$, the two redox units are separated by saturated carbon bridge composed of four single C-C bonds (Table 2), And it is, therefore, reasonable to attribute its oxidation wave to a two-electron process, As the two ferrocenyl units must behave independently without metalmetal interaction between the iron centers. ${ }^{41}$

\section{CONCLUSIONS}

In summary, we have described a high yield synthesis, using CAN-mediated $\mathrm{C}-\mathrm{C}$ bond forming reaction, of the 3-ferrocenylmethyl-pentane-2,4-dione $\mathbf{1}$, starting from ferrocenylmethanol and acetylacetone. The doubly-substituted 3,3'-bis(ferrocenylmethyl)pentane-2,4-dione $\mathbf{2}$ was isolated in excellent yield as a crystalline product upon standing a dichloromethane solution of the oily precursor $\mathbf{1}$ at low temperature. The molecular structure of the bimetallic $\beta$-diketone $\mathbf{2}$ has been resolved by single crystal X-ray diffraction. Such nonenolizable bisferrocene-containing 1,3-diketones are attractive building blocks for the construction of new polydentate Schiff bases and their corresponding transition metal complexes.

\section{Supplementary material}

CCDC-929866 contains the supplementary crystallographic data for this paper. These data can be obtained free of charge from the Cambridge Crystallographic Data Centre via www.ccdc.cam.as.uk/data_request/cif.

\section{ACKNOWLEDGMENTS}

The authors thank P. Hamon (Rennes) and Dr. P. Jehan (CRMPO, Rennes) for recording the ${ }^{1} \mathrm{H}$ NMR and ESI mass spectra of 2, respectively. This research has been performed as part of the Chilean-French International Associated Laboratory for "Inorganic Functional Materials" (LIAMIF-CNRS $\mathrm{N}^{\circ} 836$ ). Financial support from the Fondo Nacional de Desarrollo Científico y Tecnológico [FONDECYT (Chile), grant no. 1090310 (C.M. and D.C.)], the Vicerrectoría de Investigación y Estudios Avanzados, Pontificia Universidad Católica de Valparaíso, Chile (C.M. and D.C.), the CNRS and the Université de Rennes 1 is gratefully acknowledged. G.A. thanks the CONICYT (Chile) for support of a graduate fellowship.

\section{REFERENCES}

1. A.R. Katritzky, A. Pastor, J. Org. Chem. 65, 3679, (2000).

2. T. Harschneck, S. Hummel, S.F. Kirsch, P. Klahn, Chem. Eur. J. 18, 1187, (2012).

3. A.L. Baumstark, A. Choudhary, P.C. Vasquez, M. Dotrong, J. Heterocyclic Chem. 27, 291, (1990)

4. E.V. Shchegol'kov, Y.V. Burgart, O.G. Khudina, V.I. Saloutin, O.N. Chupakhin, Russ. Chem. Rev. 79, 31, (2010).

5. S. Fustero, M. Sanchez-Rosello, P. Barrio, A. Simon-Fuentes, Chem. Rev. 111, 6984, (2011).

6. Y. L. Janin, Chem. Rev. 112, 3924, (2012).

7. A.D. Garnovskii, B.I. Kharixov, L.M. Blanco, D.A. Garnovskii, A.S. Burlov, I.S. Vasilchenko, G.I. Bondarenko, J. Coord. Chem. 46, 365, (1999).

8. K.T. Mahmudov, M.N. Kopylovich, A.J.L. Pombeiro, Coord. Chem. Rev. 257, 1244, (2013).

9. G. Cros, J.-P. Costes, C. R. Acad. Sci. Paris, Ser. Iic T.294, 173, (1982).

10. G. Bett, D.E. Fenton, J.R. Tate, Inorg. Chim. Acta 54, L101, (1981).

11. J.-P. Costes, D.E. Fenton, J. Chem. Soc., Dalton Trans. 2235, (1983)

12. J.-P. Costes, Polyhedron 6, 2169, (1987) and references cited therein.

13. P. Hu, L. Zhang, X. Zhu, X. Liu, L. Ji, Y. Chen, Polyhedron 8, 2459, (1989).

14. M. Fuentealba, J.-R. Hamon, D. Carrillo, C. Manzur, New J. Chem. 31, 1815, (2007).

15. A. Trujillo, S. Sinbandhit, L. Toupet, D. Carrillo, C. Manzur, J.-R. Hamon, J. Inorg. Organomet. Polym. Mater. 18, 81, (2008).

16. M. Fuentealba, A. Trujillo, J.-R. Hamon, D. Carrillo, C. Manzur, J. Mol. Struct. 881, 76, (2008).

17. S. Celedon, M. Fuentealba, T. Roisnel, J.-R. Hamon, D. Carrillo, C. Manzur, Inorg. Chim. Acta 390, 184, (2012).

18. Y.-C. Shi, H.-M. Yang, H.-B. Song, C.-G. Yan, X.-Y. Hu, Polyhedron 23, $567,(2004)$.

19. Y.-C. Shi, C.-X. Sui, H.-B. Song, P.-M. Jian, J. Coord. Chem. 58, 363, (2005).

20. Y.-C. Shi, H.-J. Cheng, S.-H. Zhang, Polyhedron 27, 3331, (2008).

21. Y.-C. Shi, H.-M. Yang, W.-B. Shen, C.-G. Yan, X.-Y.Hu, Polyhedron 23, $15,(2004)$.

22. Y.-C. Shi, H.-M. Yang, W.-B. Shen, C.-G. Yan, X.-Y. Hu, Polyhedron 23, 1541, (2004).

23. V. Nair, L. Balagopal, R. Rajan, J. Mathew, Acc. Chem. Res. 37, 21, (2004). 
24. V. Nair, A. Deepthi, Chem. Rev. 107, 1862, (2007).

25. B. Giese, Radicals in Organic Synthesis: Formation of carbon-carbon bonds, Pergamon, Oxford, 1986.

26. X. Xu, R. Jiang, X. Zhou, Y. Liu, S. Ji, Y. Zhang, Tetrahedron 65, 877, (2009).

27. G. Ahumada, T. Roisnel, S. Sinbandhit, C. Manzur, D. Carrillo, J.-R. Hamon, J. Organomet. Chem. 737, 1, (2013).

28. J.K. Lindsay, C.R. Hauser, J. Org. Chem. 22, 355, (1957).

29. C.M. Zakaria, C.A. Morrison, D. McAndrew, W. Bell, C. Glidewell, J. Organomet. Chem. 485, 201, (1995).

30. A. Altomare, M.C. Burla, M. Camalli, G. Cascarano, C. Giacovazzo, A. Guagliardi, A.G.G. Moliterni, G. Polidori, R. Spagna, J. Appl. Crystallogr. 32, 115 (1999).

31. G.M. Sheldrick, Acta Crystallogr. A64, 112 (2008).

32. L.J. Farrugia, J. Appl. Crystallogr. 32, 837 (1999).

33. O.V. Dolomanov, L.J. Bourhis, R.J. Gildea, J.A.K. Howard, H. Puschmann, J. Appl. Crystallogr. 42, 339 (2009).
34. Repeated attempts to grow crystals of 2 suitable for single-crystal diffraction have previously been unsuccessful; see: G. Ferguson, C. Glidewell, G. Opromolla, C.M. Zakaria, P. Zanello, J. Organomet. Chem. 517, 183, (1996).

35. J.D. Dunitz, L.E. Orgel, A. Rich, Acta Crystallogr. 9. 373, (1956).

36. F.H. Allen, O. Kennard, D.G. Watson, L. Brammer, A.G. Orpen, R. Taylor, J. Chem. Soc. Perkin Trans. S1, (1987).

37. G. Ferguson, C. Glidewell, C.M. Zakaria, Acta Crystallogr. C50, 1673, (1994).

38. A.G. Orpen, L. Brammer, F.H. Allen, D. Kennard, D.G. Watson, R. Taylor, J. Chem. Soc. Dalton Trans. S1, (1989).

39. G. Ahumada, P. Hamon, V. Dorcet, T. Roisnel, C. Manzur, D. Carrillo, J. P. Soto, J.-R. Hamon, J. Organomet. Chem. 732, 40, (2013).

40. D. Braga, F. Grepioni, G.R. Desiraju, Chem. Rev. 98, 1375, (1998).

41. S. Barlow, D. Ohare, Chem. Rev. 97, 637, (1997). 